\title{
A Review: Study of Multi-ovary Wheat and Yield Contributing Traits
}

\author{
Maria Ayoub ${ }^{1, a}$, Rabia Saif ${ }^{2, b, *}$, Nawal Zafar,c, Muhammad Tariq ${ }^{4, d}$ \\ ${ }^{1}$ Cotton Research Institute, AARI, Faisalabadi, Pakistan \\ ${ }^{2}$ University of Agriculture, Faisalabad, Pakistan \\ ${ }^{3}$ Cereals and Pulses Section, AARI, Faisalabad, Pakistan \\ ${ }^{4}$ Wheat Research Institute, AARI, Faisalabad, Pakistan
}

${ }^{*}$ Corresponding author

\begin{tabular}{|c|c|}
\hline A R T I C L E I N F O & A B S T R A C T \\
\hline $\begin{array}{l}\text { Keywords: } \\
\text { Wheat } \\
\text { Multi-Ovary } \\
\text { Yield related traits } \\
\text { Genetics } \\
\text { Combining Ability }\end{array}$ & $\begin{array}{l}\text { Wheat is an essential crop throughout the world and especially in Pakistan. It has a great yield } \\
\text { potential which can cope with the raising food challenges of the world but there is a more need to } \\
\text { increase its yield with its increasing demand. There is a need to increase the yield by improving the } \\
\text { genetic characters. Breeder's intention is to find out the variability in the genetic lines and by the use } \\
\text { of these lines they can develop the high yielding breeding lines. Multi-ovary is a novel character to } \\
\text { increase the number of grains per spikelet. What type of gene actions control that? From this review } \\
\text { we get that some support the single dominant gene controlled trait, some support the two recessive } \\
\text { non-complementary genes controlled trait and some favour the both as it is controlled by both } \\
\text { dominant and recessive genes in different tri-grain lines. Secondly there is a need to study the genetic } \\
\text { variation for the yield contributing traits. So that we can improve our genotypes to attain high yield. } \\
\text { How we can evaluate yield and yield components. Combining ability is a considerable tool for this. } \\
\text { Literature revealed that additive gene action contributes more towards yield than non-additive. In } \\
\text { this many lines also came forward as good combiners which in future we can use them for a } \\
\text { successful wheat hybridization program. }\end{array}$ \\
\hline
\end{tabular}

mariaayoub33@gmail.com (iD) https://orcid.org/0000-0002-8386-5602

nawzaf20@gmail.com (iD) https://orcid.org/0000-0001-9059-4540

b@ rabiasaif03@gmail.com rabiasaif51@yahoo.com

D https://orcid.org/0000-0002-0437-8241

iD https://orcid.org/0000-0002-6368-0061

(c) (1) () This work is licensed under Creative Commons Attribution 4.0 International License

\section{Introduction}

Wheat (Triticum aestivum L.), king of cereals, belongs to Poaceae family and is one of the leading cereal of many countries including Pakistan. Wheat is the most widely grown crop worldwide over 200 million hectares. Wheat contributes $27 \%$ of World's cereal production. It provides food calories for about 4.5 billion peoples. Wheat is one of the most important and staple food of about $36 \%$ of world's population and provides $20 \%$ calories (Tripathi et al., 2011).

Wheat has paramount importance in Pakistan. Wheat accounts for 9.9 percent of the value added in agriculture and 2.0 percent of GDP of Pakistan. (Anonymous, 201516). In Pakistan wheat is among the four major crops including sugarcane, cotton and rice. Due to its importance and as a leading crop over all cereals crops there is need to develop resistant varieties against environmental stresses. For wheat improvement both modern techniques and conventional methods have been utilized. Due to its large genome size (about $17000 \mathrm{Mb}$ ) the improvement process by any method is genetically challenging.
Yield potential of recent wheat varieties is reducing with the passage of time by a number of aspects i.e. biotic factors, abiotic factors, genetic drift, contamination of cross pollination and mixing of seeds during threshing cause a fluctuation in final average yield. To overcome this reduction in yield potential, the genetic material of varieties and genotypes have to be reshuffled so that these varieties and genotypes may attain an ideal genetic makeup which would help them to give better performance in a range of changing environment. In 2050 it is expected that World's population will reach to 9 billion so increase in food grain production is required to fulfil the requirement of ever-increasing population (Echeverry-Solarte et al., 2014). World wheat demand is increasing by $2 \%$ per year however the genetic gain in yield is less than $1 \%$ and increase in yield by advanced infrastructure of agronomic practices is very expensive (Skovmand et al., 2001). So there is a need to increase yield through genetic potential, there are many traits which by improvement can increase the yield. Numbers of grains per spike is one of them and 
to increase grain number, increase in the level of fertility of spike is required (Skovmand et al., 2001). For obtaining high grain number per spike wheat scientists used a wide genetic variability in the wheat morphological structure. Multi-ovary wheat is a novel character to increase the grain number because it has three pistils in every floret (Wang et al., 2009). Average number of grains per spikelet in our common wheat varieties is 3 , if on an average 18 spikelets per spike considered then 54 grains per spike are produced. If multi-ovary produces 2 grains per floret then 6 grains per spikelet (108 grains per spike). If multi-ovary produces 3 grains per floret then 9 grains per spikelet (162 grains per spike) and most of the time multi-ovary is trigrain ( 3 grains per floret) because it is highly heritable character controlled by nuclear genes.

Development of genotypes with high yield is a main objective of any wheat breeder in the country and all over the world. Identification of genotypes with desirable characters and the assessment of combining ability effects for characters related to yield of a crop would be important in an effective breeding program. Therefore, development of high-yielding varieties needs detailed information of the prevailing genetic variation for yield components. One of the primary goals of any breeding program is to produce improved quality lines with high yield for release as cultivars to growers. The prerequisite to attain this goal is to find adequate amount of variability, in which desired genotypes are to be selected. Introduction of new cultivars could be done from one region to the other simply and may be used for further operation to develop breeding lines.

Therefore, thorough knowledge of the existing genetic variation is required for yield and its components for the development of high-yielding varieties. The main aim of the breeder is to find sufficient amount of variability, in which desired lines are to be selected in order to develop breeding lines for the production of new cultivars. Line $x$ tester analysis is powerful method to estimate the combining ability effects and gene action. This helps in selection of crosses for exploitation and desirable parents in wheat breeding program and provides information regarding genetic mechanisms controlling certain traits.

The objective of this review was to study:

- The evaluation of multi-ovary trait in wheat and how to use this novel trait in our common wheat varieties.

- Secondly evaluation of yield and yield components on the basis of combining ability effects for the selection of best combiners for a successful wheat hybridization program. Thus information attained would be useful in future for selecting desired parents and their crosses to develop an effective breeding program and enhancement of wheat yield.

\section{Multi-ovary Wheat}

Multi-ovary wheat has three pistils in every floret (Wang et al. 1987), having three gynoecia in each floret results in three grains per floret (Wang et al. 2009). There is no difference in tri-grain wheat and common wheat from flower initiation to flower differentiation and development observed by light (LM) and scanning electron microscope (SEM) (Yao-zhi and Hui-bin 1989). The only difference between tri-grain wheat and common wheat is that tri-grain wheat has three gynoecia instead of one (Wang et al. 2009). The process of megasporogenesis and embryo sac development are the same in common wheat as well as in tri-grain wheat (Wang et al. 1987). The additional pistils are present in tri-grain wheat while the primary pistil developed first (Wang et al. 1987) and differentiation of florets continue (Wang et al. 1990) so, the additional pistils are formed by periclinal division of sub-hypodermal cells in the axil of lodicules. Although additional pistils formed later but mature before blooming because the female gametophyte develops quickly (Yao-zhi and Hui-bin 1989). Normally all pistils were fertile (Yao-zhi and Huibin (1989) and productivity of additional pistils is similar to the primary pistil (Wang et al. 1990).

Sometimes some abnormal structures are formed in trigrain wheat (Wang et al. 1987).

- Additional complex spikelet formed at the base of spikelet.

- Additional florets formed in floret and also additional florets present between lodicules and additional pistil.

- Each ovary has two even three ovules.

- Double embryo sac and multicellular archesporium formed in an ovary.

- Some archesporiod cells formed on top of inner integument.

- Ovaries may fuse each other.

\section{Study of Multi-Ovary Wheat}

The multi ovary gene control the three grain trait in trigrain wheat and it is also known as multi gynoecia $(\mathrm{Mg})$ gene. The $\mathrm{Mg}$ is dominant in nature and it is located on distal region of 2D chromosome (Wang et al. 2009). Two recessive non-complementary genes, $\mathrm{m} 1$ and $\mathrm{m} 2$ control the multi-ovary character and these genes are present on 5DS and 6BS chromosomes respectively (Shen 1992) this statement is also confirmed by Tong, and he marked the gene as mo1 and mo2 instead of $\mathrm{m} 1$ and $\mathrm{m} 2$ (Tong and Tong 1984). The multi ovary character penetrance depends on nuclear gene not on cytoplasm (Guo-hui et al. 2008).

Tong and Tong (1984) studied that multi-ovary lines of common wheat have 2-3 well developed ovaries per floret. They used the 22 lines of Chinese spring monosomic and disomic lines as female parent and a multi-ovary line as male parent. Cytological analysis of $F_{1}$ hybrid progenies showed that crosses of monosomic-5D $\times$ multi-ovary and monosomic-6B $\times$ multi-ovary produced the multi-ovary phenotypes. All other monosomic and disomic not produced multi-ovary phenotype in their $F_{1}$ generation. Hence concluded that multi-ovary character is controlled by two recessive non-complimentary genes, named as multi-ovary genes denoted by mo1 and mo 2 and they are located on 5D and 6B chromosomes, respectively.

Wang et al. (1987) selected a new type of wheat which has three pistils in every floret and known as trigrain or multi-ovary wheat. The process of megasporogenesis and embryo sac development are the same in common wheat as well as in trigrain wheat. The additional pistils are present in trigrain wheat while the primary pistil developed first. 
Sometimes some abnormal structures are formed in trigrain wheat.

- Additional complex spikelet formed at the base of spikelet.

- Additional florets formed in floret and also additional florets present between lodicules and additional pistil.

- Each ovary has two even three ovules.

- Double embryo sac and multicellular archesporium formed in an ovary.

- Some archesporiod cells formed on top of inner integument.

- Ovaries may fuse each other.

Yao-zhi and Hui-bin (1989) investigated the phenomenon of flower development in multi-ovary wheat by LM and SEM. They concluded that there are no differences in multi-ovary and common wheat from flower initiation, emergence of lodicules and flower differentiation to development of flower. The additional pistils are formed by periclinal division of sub-hypodermal cells in the axil of lodicules. Although additional pistils formed later but mature before blooming because the female gametophyte develops quickly. Normally all pistils were fertile.

Wang et al. (1990) used the scanning electronic microscope and paraffin section method to study the differentiation process of florets and the three pistils of trigrain wheat. It is observed that the differentiation process of florets in a trigrain wheat is just the same as in common wheat, but floret differentiation does not stop after the formation of lodicules and primordia of stamen and pistil and other two additional pistils are gradually formed by periclinal division of sub-hypodermal cell in the axil of lodicules. According to their origin, the additional pistils are without carpellody and different from the primary pistil, which comes from meristem tissue at the top of the floret. Although the additional pistils occur late, they achieve maturity and get normal fertility as the primary pistil does during the blooming, that they develop quickly after style-formation.

Shen (1992) made the crosses between "Chinese Spring" monosomic lines and multi-ovary line for localization of gene multi-ovary on chromosome and chromosome-arm in common wheat. The results showed that two recessive non-complimentary genes controlled the multi-ovary trait and they were found to be on chromosomes $5 \mathrm{D}$ and $6 \mathrm{~B}$, and they are named as $\mathrm{m} 1$ and $\mathrm{m} 2$ respectively. It was indicated that $\mathrm{m} 1$ and $\mathrm{m} 2$ genes were located on the chromosome 5DS and 6BS respectively as result of ditelosomic analysis of $\mathrm{F} 1$ made by reciprocal crosses.

Huibin et al. (1992) observed that the development of male gametophyte and microsporogenesis are same in common wheat and in trigrain wheat. Sometimes abnormalities were seen e.g. chromosomes spread outside the equatorial plate, micronuclei and chromosome bridges were found in meiosis. During anaphase II naked nucleus, macronucleus, micronucleus and polyad were appeared. In trigrain wheat during male gametophyte development i.e. large microspores, multinucleate pollen, homogenous 2 or 3 nuclei pollen, forked 2-celled pollen and 3 -sperms pollens were observed.
Shou-cai et al. (2002) study the heterosis and utilization of multi-ovary wheat by developing hybrids of multi-ovary wheat. The results showed that: The heterosis of plant height, kernels per head, grain weight per plant, 1000 kernels weight decreased in this order. Hybrid of multiovary wheat had very high heterosis in the grain weight per plant, there is a $32.71 \%$ increase of yield as compared with the average of both parent in 18 crosses, among 12 crosses increased $3.41-42.84 \%$. The heterosis mainly showed higher kernels per head, the application of multi-ovary wheat should strengthen the improving of other agronomic characteristics.

Shou-cai et al. (2007) evaluate the genetic background of multi-ovary character in wheat by developing near isogeneic lines lines (NIL). They develop two NIL, M04309-1 and M04309-3 by using duoII as donor parent and $77(2)$ as recurrent parent that are dwarfing sterile wheat genotypes. They used acid polyacrylamide gel electrophoresis (APAGE) to analyze the location of multiovary gene through successive backcrossing and crossing. They concluded that both NIL was highly genetically stable for multi-ovary wheat.

Guo-hui et al. (2008) concluded that multi-ovary character penetrance is due to nuclear gene. They used multi-ovary varieties of homonucler-homoplasmic, heteronucler-homoplasmic and homonucler-heteroplasmic with different Aegilops cytoplasm to improve hybrid seed production of wheat. They used the software DPS7.05 for analysis of variance and results showed that penetrance of first, second and third grain per floret have no significant differences in case of homonucler-homoplasmic and homonucler-heteroplasmic multi-ovary varieties. While in case of heteronucler-homoplasmic multi-ovary wheat varieties penetrance showed significance.

Wang et al. (2009) studied the inheritance pattern of three grain trait in wheat. They described that this trait is controlled by a single dominant gene from analysis of segregation of cross between IGDB-TW (trigrain wheat) $\times$ Chinese Spring and that gene was marked as $\mathrm{Mg}$ (multiple gynoecia gene). They tested about 339 microsatellite markers by bulked segregation analysis (BSA) to identify the SSR markers linked with Mg gene. Six SSR markers were linked with $\mathrm{Mg}$ gene on chromosome 2DL. They also detected that $\mathrm{Mg}$ gene was located on distal region of chromosome 2DL by using 2D deletion lines of Chinese Spring.

Dong-xu et al. (2010) study the multi-ovary character a new peculiar property of wheat, had an improvement of grains per spike obviously, and could improve the propagation efficiently. They develop 23 NILs of multiovary wheat and 42 pairs of SSR primers were selected. The results of SSR analysis showed that:

- 92 bands produced as a result of amplification of 42 pairs of SSR primers, 53 bands $(57.61 \%)$ were polymorphic and 30 pairs $(71.43 \%)$ of primers were polymorphic.

- The genetic similarity coefficient of NILs and their recurrent parents was between 0.77 and 0.95 , with an average of 0.88 .

- Cluster analysis revealed NILs and their recurrent parents into 7 clusters with the similarity coefficient of $0.84 .70 .83 \%$ of them were clustered into the first cluster; the first cluster included 3 subclasses. 
The multi-ovary material 2008H69 was the least different with the recurrent parent and was clustered into a small class with the similarity coefficient of 0.93 .

Xian Fang et al. (2011) a distinctive germplasm of wheat having multi-ovary character is used for seed production of hybrid wheat because it has more grains per spike. They construct NILs of multi-ovary and mono-ovary lines from BC4F3 by using SSH technique. 12 genes were choosing to analysed the expression patterns by RT-PCR. There were eight genes showing significant differential expression between multi-ovary and mono-ovary lines. At $1 \sim 12 \mathrm{~mm}$ developmental stages of ears the genes were significantly up-regulated and the expression level is high in stem shoot meristem than any other tissues. This showed that genes differentially expressed in multi-ovary and mono-ovary lines may participate in diverse biochemical and physiological processes that might be responsible for the formation of the multi-ovary characteristic.

Xian Fang et al. (2011) study the expression pattern and genome structure of RPL21 gene which encodes 60S ribosomal protein. cDNA and DNA sequences of RPL21 gene was isolated from multi-ovary lines and characterized by RT-PCR. Semi-quantitative RT-PCR was used to analyze the differential expression of genes between the mono-ovary and multi-ovary lines and expression patterns of gene in different development stages of ears and different tissues of multi-ovary lines. The results showed that gene expression in $2 \sim 4 \mathrm{~mm}$ ears of multi-ovary line was higher than mono-ovary line. This gene was upregulated with the development of young ear of multiovary line and arrived at the highest expression levels at 8 $\sim 9 \mathrm{~mm}$ young ear stage. It was speculated that more RPL21 were needed for the growth and development of floral organ. The expression level of RPL21 genes in multiovary line was the highest in rapidly growing tissues.

Xian Fang et al. (2011) study the effect of RPS15a gene, which encode the $40 \mathrm{~S}$ ribosomal protein $\mathrm{S} 15 \mathrm{a}$, on the formation of multi-ovary in wheat. The expression patterns of the gene in different material, different development stages of ears in multi-ovary line and different tissues of multi-ovary line were analysed by semi-quantitative RTPCR. The results showed that the expression level of the gene in 2-4 mm ears of multi-ovary line was higher than that in mono-ovary line. This gene was upregulated with the development of young ear, and the highest levels of expression at period of 8-9 mm. Therefore the RPS15a gene may involve in the information of multi-ovary because it differentially expressed in multi-ovary and mono-ovary lines.

Zai-jun et al. (2012) evaluated the near isogentic lines for three pistil trait by SRAP markers. Three pistil (TP) trait is an important mutant trait in wheat breeding. They used 3 pistil material as donor parent and 4 recurrent male parents were Chinese Spring, Chunmai 28, Mianyang 29 and Neimai 9. 4 NILs (CSTP, CM28TP, MY29TP and NM9TP) were developed after backcrossing for 7 generations and then selfing for 4 generations. Genetic distance and genetic similarity were compared and analyzed by SRAP markers. The results revealed that:

- 120 pairs $(93.8 \%)$ of primers create polymorphic bands and about 638 bands $(65.2 \%)$ were polymorphic out of 128 pairs of SRAP primers amplified 978 bands.
- The genetic similarity coefficients were 0.9346, 0.9397, 0.9070 and 0.8732 for CSTP, CM28TP, MY29TP and NM9TP with their recurrent parents respectively.

- $\quad$ CSTP and CM28TP were clustered into a small class having 0.93 similarity coefficient because cluster analysis revealed that CSTP and CM28TP showed less differences with their recurrent parent.

Zai-jun, Y. and P. Li-juan et al. (2013) analysed the heritability of some main agronomic traits in three pistil mutants of wheat. They choose nine characters i.e. plant height, spike length, internode length below spike, stem diameter, flag leaf length, flag leaf width, the second top leaf length, the second top leaf width and spikelet numbers and calculated these characters in blooming stage. The results revealed that broad sense heritability for nine characters were high, $63.38 \%$ to $96.53 \%$. Plant height, spike length, inter node length below spike, flag leaf length and the second top leaf length were controlled by additive gene effect because these traits had high narrow sense heritability, so these characters could be selected in early generations. While other agronomic traits stem diameter, flag leaf width and the second top leaf width could not be selected in early generations because these had less narrow sense heritability.

\section{Combining Ability}

The concept of combining ability is important in designing plant breeding programs. It is especially useful in testing procedures, where it is required to study and compare the performance of lines in hybrid combinations. Combining ability or productivity in crosses is defined as the ability of parents or cultivars to combine amongst each other during the process of hybridization so that favourable genes/characters are transmitted to their progenies. Two type of combining ability, general and specific, have been recognized in quantitative genetics. Specific combining ability is defined as the deviation in the performance of hybrids from the expected productivity based upon the average performance of the lines involved in the hybrid combination, whereas general combining ability is defined as average performance of a line in series of crosses. According to Sprague and Tatum (1942), general combining ability is due to genes which are largely additive in their effects and specific combining ability is due to genes with dominance or epistatic effect. Rawlings and Thompson (1962) used line $\times$ tester analysis to estimate GCA and SCA of inbred parents. Since the development of new cultivars through hybridization is a continuous process, information on combining ability of new cultivars remains important. Line $\times$ tester analysis of combining ability was developed by Kempthorne (1957). Line $\times$ tester can be efficiently used in order to evaluate large number of parents for general and specific combining ability. The same scheme to calculate the combining ability effects in wheat and other species has been previously described by Narro et al. 2003 and Shoran et al., 2003. Combining abilities (GCA, SCA) may be estimated based on the data from the experiments with $F_{1}$ and $F_{2}$ hybrids (Cox and Murphy 1990; Oettler et al. 2001; Acquaah, 2006). In this study, the $F_{2}$ hybrids were analysed as it was necessary to 
obtain sufficient amount of grains to determine the rheological properties. As it is known in $\mathrm{F}_{2}$ hybrids $50 \%$ of loci are in heterozygous state. The selection and development of new genotypes of a particular crop is a continuous need due to natural segregation of parental characters.

\section{Study of Yield Related Traits}

Cheema et al. (2007) studied gene action for grain yield and some economic characters in 25 crosses of spring wheat under arid conditions. Results revealed highly significant genotypic differences for traits like No. of tillers, length of main length, No. of spikelets, No. of seeds, 1000 seed weight and seed yield. Analysis of combining ability showed that variances of SCA were significantly greater than GCA and reciprocal effects. In all characters under study, main part of the total mean square was attributable to the specific combining ability effects representing that these traits were mainly controlled by non-additive gene action. Crosses GPW-272 $\times$ GPW-36, GPW-272 $\times$ GPW-37 and GPW-273 $\times$ GPW-37 found as good specific combiners to produce segregants with greater No. of tillers, No. of seeds and maximum grain weight summarizing in production of wheat genotypes with high yield for arid regions.

Gorjanovic and Balalic (2007) used the line $\times$ tester analysis to study the combining ability and gene effects in durum wheat for some characters like spike length, plant height and No. of spikelets/spike. Results showed that in the inheritance of plant height, number of spikelets/spike, non-additive genes have important role than additive genes. Variety Belfugito was best general combiner for No. of spikelets/spike and plant height and combined good in two hybrids: Belfugito $\times$ Alifen and Belfugito $\times$ Yavaros 79. Most of the studies concluded that two genetically different genotypes, having one genotype as a good general combiner, when crossed they shows good specific combining ability (SCA) effects.

Kamaluddin et al. (2007) analyzed the wheat genotypes along with their $F_{1}$ and $F_{2}$ generation for Characters like seed yield/plant and 1000 seed weight. Component analysis showed significant effects for general and specific combining ability in $F_{1}$ and $F_{2}$ generations for the characters under study. For all measured characters the effects of GCA were significant than SCA, showing the preponderance of additive genetic effect. Cross combinations exhibiting high specific combining ability effects for yield and seed weight were seen to be originated from parents having different general combining ability effects. The single seed descent method could be used to determine additive genetic effects while dominance genetic effects could be prominent for hybrid development in wheat breeding programs. Among the parents, genotypes from the International Maize and Wheat Improvement Center (CIMMYT) and South Asia were best general combiners for grain filling duration. Similarly, cross combinations including different parents from CIMMYT and South Asia exhibited significant specific combining ability effects for different characters.

Khan et al. (2007) evaluated the wheat genotypes for combining ability analysis. Data were recorded for yield contributing traits from $\mathrm{F}_{1}$ generation. Non-additive gene effects were functioning for number of tillers/ plant and 1000-grain weight. While plant height, number of grains/spike and grain yield/plant were controlled by additive gene effects. For grain yield, 1000-grain weight, number of tillers/plant and plant height "Uqab 2000" proved to be good general combiners. While V-00055 showed good general combining ability for plant height and No. of grains/spike. When grain yield was concerned then the cross "SH-02 $\times$ Uqab 2000" and its reciprocal and "V-00125 × V-00055" were best specific combiners for all yield related characters.

Memon et al. (2007) evaluated genetic mechanisms viz., coefficient of variability $(\mathrm{Cv})$, genetic variance $(\mathrm{Vg})$, heritability percentage (h2\%) and genetic advance (GA) in some yield related quantitative traits. Highly significant differences were observed for characters under study among all the genotype. Different responses for various characters had been observed among all crosses. In progeny Khirman $\times$ RWM-9313 high genetic advance with maximum heritability were obtained for plant height, spikelets per spike and grains per spike. Progenies of two crosses Soghat-90 $\times$ Sarsabz and Marvi-2000 $\times$ Soghat-90 presented high heritability with more No. of tillers/plant, spike length and grains/spike. High grain yield with more No. of tillers/plant were observed in a parental line Khirman.

Suleyman and Akguni (2007) made crosses between 6 lines and 7 tester bread wheat (Triticum aestivum L.) cultivars by line $\times$ tester in 1999-2000 growing at konya, a representative part of central Anatolia, in order to study combining ability and genetic parameters for yield and yield associated traits. Plant height, spike length, number of spikelets per spike, fertile tillers per plant, number of grains per spike, 1000 grain weight and grain yield per plant were determine in all parents and their hybrid progenies. The analysis of combing ability indicated that a large portion of the total genetic variation was associated with non-additive gene action. Magnitude of SCA variance was more pronounced than GCA variance for all the traits.

Dagustu (2008) introduced new germplasm in breeding programs in Turkey, three lines viz. Samsun/Bafra - 333 (SB- 333), Samsun - 46 (S - 46), Population - 311 (P - 311) and four varieties namely Pehliva, Marmara - 86 (M - 86) and Gonen, Golia in bread wheat. They crossed these seven genotypes in all possible combination. They performed genetic analysis variance, combining ability, correlations, and path coefficient analysis to evaluate characters like seed yield/ear and agronomic traits including plant height, length of spike, No. of spikelet, No. of seeds/spike and 1000 seed weight. Significant differences were obtained among genotypes and their progenies. For all parameters GCA effects were highly significant, whereas SCA effects were significant only for plant height, seed yield/ear and 1000 seed weight. General reciprocal effects for plant height and seed yield/ear and the correlations for seed yield/ear and in both years yield parameters were significant. Path analysis showed that No. of seeds had the highest effect on seed yield/ear, following No. of tillers. The genotypes S - 46 and Gonen for No. of seed and for 1000 seed weight and seed yield/ear P-311 and SB-333 exhibited positive general combining ability values in both years. They could be best in the development of genotypes with desired character in breeding programs. 
Dhadhal et al. (2008) analysed the combining ability and gene action. They used 11 females and three males and crossed them in line $\mathrm{x}$ tester fashion in wheat. The results revealed the significance of additive and non-additive gene actions for almost all yield related traits. Grain yield per plant, days to heading, days to maturity, spike length, spikelets/spike and 1000-grain weight were inherited through additive gene action. The lines HUW 234, GW 322, GW 273, 7C Nad 63 tab's, MP 3077 and tester PBW 373 were good general combiners for yield components. For spike length, No. of spikelets/spike, No. of grains/spike and 1000-grain weight the cross Chilero x GW 173 was proved to be the best as having high specific combining ability effects.

Haq et al. (2008) evaluated ten wheat genotypes for yield components to estimate genetic advance and heritability. High values of heritability and more genetic advance have been observed for No. of grains/spike, 1000 grain weight and grain yield/plant. Spike length exhibited moderate broad sense heritability with low genetic advance. Moderate heritability estimates proposed that selection should be postponed to advanced generations for this character. Low genetic advance indicates slight chances of improvement of this trait in succeeding generations.

Kashif and Khan (2008) evaluated seven wheat genotypes to detect combining ability effects for yield associated characters i.e. plant height, effective tillers, spikelets/spike, kernels/spike, 1000-kernel weight and yield/plant. Plant height showed high additive and over dominance variance under both sowing conditions. They reported that best general combiner for effective tillers, spikelets/spike, kernels/spike and yield/plant was GA2002. For 1000-grain weight the best combiner was Chenab 2002. Cross GA-2002 $\times$ SH-2002 was proved as a valuable in selection of high yielded genotypes.

Mahpara et al. (2008) conducted an experiment to analyse combining ability among Shahkar-95, Parwaz-94, Iqbal-2000, Uqab-2000, MH-97, 4072 and Punjab-96. They examined different plant morphological characters like leaf area, plant height, tillers/plant, peduncle length, extrusion length, spike length, spikelet/spike, spike density, grains/spike, 1000-grains weight and grains yield/plant. There were significant differences for GCA and SCA among genotypes. The greater magnitude of $\sigma 2 \mathrm{~g}$ than $\sigma 2 \mathrm{~s}$ for all characters was detected except for grain yield/plant and plant height, representing that additive gene action had importance in the inheritance of characters. It was evident that non-additive gene action contributed in the inheritance of grain yield/plant and plant height. Varieties Punjab-96, Uqab-2000, Iqbal-2000 and MH-97 were best general combiners for nearly all studied characters, correspondingly. Hybrids Iqbal-2000 $\times$ Parwaz-94, Parwaz-94 × Uqab-2000 and Punjab-96 × 4072 appeared to be the best specific combiners.

Oettler et al. (2008) reported that eight agronomic characters and determine their general and specific combining ability variance. They conducted line $\mathrm{x}$ tester study containing six female lines and four testers and evaluated $24 \mathrm{~F}_{1}$ hybrids with their parents at two places. For grain yield specific combining ability effects were significant and its value ranged from 4.6 - $6.8 \mathrm{dt} / \mathrm{ha}$. Most of the variation was explained by general combining ability $\times$ place interaction. Predominant general combining ability effects were observed for thousand grain weight. In FN most of the variation was due to specific combining ability and interaction with places, while for plant height negligible interaction was reported.

Akbar et al. (2009) estimated combining ability effects for some agronomic characters in wheat through line $x$ tester analysis. Four varieties/lines were used as female (lines) named as HI666/PVN"S", HUBARA"S", Faisalabad-85 and Faisalabad-83. As a tester genotypes Faisalabad-08 PBW65 / ROER / 3 / PB6 // MIRLOW / BUC and PBW502 were used. All yield related characters including days to $50 \%$ heading, days to $50 \%$ maturity were estimated. Of these two lines that are Faisalabad 83 and Faisalabad-85 were good general combiners for various agronomic characters. The tester PBW65 / ROER /3/ PB6 // MIRLOW / BUC was shown as good general combiner for character under study in addition to grain yield. For all characters Faisalabad-85 × PBW502 and Faisalabad-83 x PBW65 / ROER /3/ PB6 // MIRLOW / BUC performed better. Ratio of Specific and general combining ability generally presented non-additive gene action for all characters. Improved genotypes with better agronomic traits were recommended by selecting advanced segregating generations of crosses.

Krystkowiak et al. (2009) conducted an experiment to evaluate the specific combing ability and heterosis effects for pant height, flag leaf area, 1000 grain weight and grain yield per plant. The experiment comprised 18 parental genotypes of wheat and $76 \mathrm{~F}_{2}$ hybrids obtained after crossing in a line $\times$ tester scheme. Parents and hybrids were examined in a field experiment conducted in a randomized complete block design with replications. SCA as well as mid-parent heterosis effects were estimated for selected morphological traits. Out of 76 cross combinations, significant SCA effects were detected in 15 crosses for plant height and 1000 grain weight, in 30 crosses for grain yield per plant and in 10 crosses for flag leaf area. The analysis of variance showed significant both GCA and SCA variances $(\mathrm{P}<0.01)$ for both 1000 grain weight and grain yield per plant. Generally, SCA variances were lower than GCA, it was observed especially for 1000 grain weight.

Yucel et al. (2009) crossed five bread wheat varieties were crossed to estimate the mode of inheritance and combining ability and the correlation in physical properties of grains. Component analysis for combining ability presented that additive as well as non-additive genetic effects were governing most of the characters. Extents of GCA for all components excluding seed weight and seed height were greater than those of specific SCA. The GCA effect was more noticeable for eight out of ten characters in relation with GCA to SCA ratio. Path coefficient analysis presented that seed width, No. of seeds and seed height had the maximum significant direct and indirect effect on most of parameters. Results gained from this research would be useful for production of new wheat cultivars with good seed characters for improvement in milling and baking quality.

Saeed et al. (2010) crossed six wheat cultivars/lines viz; Baviacore, Nesser, 9247, 9252, 9258 and 9267 to develop $30 \mathrm{~F} 1$ crosses. They tested them along with their parents under normal and water stress conditions. They numerically analyzed some traits like No. of grains per 
spike, spike density, 100-grain weight, biological yield and harvest index. Among genotypic means differences were significant in all characters under both conditions. GCA and SCA differences were significant for all measured traits except 100-grain weight and spike density in both conditions. For No. of grains per spike and harvest index Baviacore was best general combiner under both conditions. Variety 9252 was best general combiner for 100 -grain weight under both conditions. The cross $9252 \times$ Nesser presented maximum SCA value for spike density and biological yield under irrigated while for 100-grain weight under water deficit condition. The cross combination $9258 \times 9252$ revealed highest SCA for No. of grains per spike under irrigated although cross $9258 \times$ Nesser under stress. For 100-grain weight the cross containing 9267 and Nesser exhibited maximum SCA under irrigated condition while spike density under stress. When grain yield and harvest index was concerned $9258 \times$ 9247 was best specific under irrigated environment while $9267 \times 9258$ under stress environment.

Ahmad et al. (2011) evaluated the performance of eight genotypes of wheat viz. Inqalab-91, Wafaq-2001, Tatara, Iqbal-2000, Margalla-99, Takbeer, Ghaznavi-98 and Khattakwal under early, normal and late sown conditions. Data were recorded for traits like days to heading, No. of tillers, No. of seeds, 1000 seed weight and yield/plant. For all characters highly significant genotypic differences were obtained. Analysis of variance showed significant additive and dominant genetic variances for days to heading, No. of tillers, No. of seeds, 1000 seed weight and yield/plant under early sowing conditions. Under normal sowing conditions both dominant and additive genetic components were significant for these characters. Likewise, under late sowing conditions significant additive and dominant genetic components were obtained for No. of seeds and yield/plant, whereas for 1000 seed weight only additive genetic component was significant. Genetic analysis of characters proved the contribution of additive as well as non-additive genetic effects in controlling their heredity.

Akram et al. (2011) estimated mean squares for quality and yield traits in spring wheat and their combining ability effects. Significant GCA effects were observed for characters under study except in days to maturity, while SCA effects were significant except for grain yield, flag leaf area, spikelets/spike, protein and lysine contents. The SCA mean square was greater than GCA representing the significance of non-additive gene action. Among parents, Chakwal 97 and Kohistan 97 were best general combiners for grain yield/plant. Shahkar 95 was better combiner for plant height, tillers/m2 and No. grains/spike. Cross combination Pothowar 93 x Kohistan 97 presented the highest specific combining ability effects for 1000 seed weight. For grain yield/plant maximum SCA values were observed for the cross Pak 81 x Kohistan 97.

Kapoor et al. (2011) studied the combining ability and nature of gene action for yield and its related characters in winter and spring wheat (Triticum aestivum L.). Ten winter wheat lines used as females were crossed with three spring wheat genotypes used as male in line $\times$ tester mating design. Good GCA was observed in four winter wheat lines namely Drina NS 720, WW-7, China 84-40022, and Nordresprez for grain yield and three other yield related characters. Two winter wheat genotypes Raj 3765 and
PBW 343 were the best general combiners for yield and its component characters. For all characters under study, mean square for SCA was more important. Cross combinations WW-7 $\times$ Raj 3765, Drina NS $720 \times$ PBW 343, Nordresprez $\times$ PBW 343, China 84-40022 $\times$ PBW 343 and Vir 453-47 $\times$ PBW 343 showed significant positive specific combining ability effects for yield parameters.

Majeed et al. (2011) investigated the potential of nine spring wheat genotypes for hybrid development. For hybrid development in wheat it is necessary to estimate the effects of combining ability and gene action for components of yield. They used line $\times$ tester technique to estimate the combining ability and gene action for characters estimating yield by using six wheat varieties as lines along with three testers to develop $18 \mathrm{~F} 1$ cross combinations. Among female varieties Chakwal-86, Chakwal-97 and Punjab-81 exhibited good GCA for most of the characters. Among varieties used as male, Pavon-76 and Faisalabad-83 showed good GCA for almost all traits. Performance of cross combinations LYP-73 $\times$ LU-26, Chakwal-97 $\times$ Faisalabad- 83 and Chakwal-97 $\times$ Pavon-76 was better for studied characters. Mean square values of GCA and SCA showed preponderance of non-additive genetic effects for all yield parameters.

Tonk et al. (2011) estimated gene effects for some agronomical characters using six generations of cross combination having two varieties Basribey and Atilla-12. Study was conducted to improve some agronomical characters of Basribey. Results of study revealed that in addition to dominance and additive gene actions, epistasis type of gene actions were significant for all studied characters due to different backgrounds of the genotypes. Due to the presence of epistasis type of gene action it would be suggested that selection will be successful in advanced generations.

Tsenov and Tsenova (2011) evaluated the combining ability and the heritability mechanisms in a group of wheat genotypes, which varied considerably by their days to heading and day to maturity. Six winter wheat genotypes were crossed in all possible combinations. During three consecutive years, the early F1 and F2 hybrid progenies were evaluated. Cultivars were assessed for combining ability and the breeding value of each combination was evaluated for these two characters. Within 5-7 days significant variations in the expression of these characters were observed among varieties. The values of general combining ability were largest as regulating the values of specific combining ability in the analysis of variance done on the whole crossing system. This was indication for dominance and additive gene effect of the genes controlling these characters. General combining ability of cultivars were directly associated to the expression of the two characters, the correlation was so high. The heritability of these characters was parallel and caused due to complex combinations of genes with additive or dominant effects. The higher magnitude of variation between parental varieties in a combination with these traits, the higher the inheritance values of days to heading and days to maturity. The regularities in the gene action and the combining ability of the varieties by days to heading were totally analogous for the character days to maturity, too. This shows that earliness could be simply assessed by days to heading. Varieties Vratsa, Obriy and Pliska, had maximum combining ability for earlier days to heading and maturity. 
Gowda et al. (2012) investigated the magnitude of mean squares of GCA and SCA effects and their interaction with environments in wheat. They evaluated four data sets generated in commercial hybrid winter wheat breeding programs with a total of 940 hybrids. In three experiments, GCA mean square for females, SCA mean square, GCA of females, environment interaction mean squares, GCA of males, times environment interaction mean square were significantly larger than zero but GCA variance for males was significant only in fourth experiment. For third experiment differences were significant among best hybrid and the best commercial cultivar. In contrast, $1.8 \%$ hybrids in second experiment and more than $21 \%$ hybrids in first and fourth experiment significantly performed the superior commercial cultivar. Therefore, selection based on general combining ability effects is favorable in hybrid development in breeding wheat.

Jain and Sastry (2012) determined the GCA and SCA for yield contributing traits. For this purpose they crossed six lines with four testers. The mean square due to general and specific combining ability revealed significant variation for most of the traits which presents the occurrence of both non-additive and additive gene effects for controlling the expression of these traits. The GCA and SCA variances ratio suggested that the presence of nonadditive gene effect was predominant for most of the traits. Varieties viz., HD-2687 and WH- 542 among lines and K65 and Raj.-3077 among testers were adjudged the best general combiner as it depicted high GCA effect in desirable direction for yield contributing characters. Among the selected hybrids WH-542 $\times$ Raj-3077 and WH $542 \times$ K-65 were exhibited highest magnitude of positive significant SCA effects for grain yield.

Rashid et al. (2012) evaluated six wheat genotypes to analyze the gene action for yield estimating characters. For all studied components differences were highly significant among the genotypes. The graphical representation showed that additive and partial dominance gene effects controlled the No. of tillers/plant, height of plant, awn length, heading date and yield/plant, whereas over dominance controlled the characters as weight of 1000 grains and maturity days. Epistasis was not present for all the characters. Distribution of recessive and dominant genes for yield components was also detected. In Lasani-2008 maximum dominant genes were observed for yield. It was suggested that selection should be done in early generations when additive gene action with partial dominance will be present. In contrast, in the presence of over dominance gene effects selection would be delayed.

Shabbir et al. (2012) determined the genetic mechanism in yield and related traits of Triticum aestivum. They crossed four females 99FJ03, Chakwal-50, T2 and Borlaug M-95 and six males Croc1/Ae.sq.205//BCN/3/2/Kauz, T23, Pak-81, Uqab-2000, GA-2002 and Margalla-99 through line $\mathrm{x}$ tester method. These genotypes were evaluated for days to heading, flag leaf area, plant height, tillers/m2, spike length, grains/spike, 1000-grain weight and yield/plant. For all characters significant differences were observed among the genotypes, it also suggested that these genotypes could be helpful in further upgrading of characters. 99FJ03 was best general combiner for characters under study except for grain yield/plant and days to heading. Tester Uqab-2000 was best general combiner for all characters except days to heading, tillers/m2 and yield/plant. Performance of 99FJ03 $\times$ Margalla-99 was well for all characters except spike length. In the same way, for cross combination 99FJ03 $\times$ Uqab-2000 higher SCA effects were observed for days to heading and 1000-grain weight. Ratio of GCA/SCA variances showed non-additive gene action for these traits and suggested that selection will be useful in succeeding progenies.

Srivastava et al. (2012) evaluated 12 components characters in wheat through line $\mathrm{x}$ tester analysis by using 12 lines and 4 testers. The variances of SCA were greater than GCA for all traits representing the significance of nonadditive gene action, which may be valuable in heterosis breeding. WH542 and HD2285 were good general combiners for yield related characters like spike length, 1000 grain weight etc. So when these varieties will be used in crosses and careful selection will be done then they may have chances for getting better recombinants. Crosses like PBW459 × RAJ 3777, K9006 × UP2425and HD2285 × UP2425 possibly combined most of the yield related characters.

Zare-kohan and Heidari (2012) crossed five genotypes of wheat adl, Chamran, Shiraz, Darab2 and Marvdasht to attain genetic information for seed yield and maturity, which were examined using Griffing (1956) model. Genotypes and their F2 generations were grown at two different places. The characters of importance were grain filling duration, seed yield/plant, plant height and days to heading and maturity. Significant genotype $\times$ site interaction was observed for plant height and grain filling duration, but interaction was absent for days to heading, days to maturity and seed yield. The mean square due to GCA and SCA were significant for all the characters. Therefore, additive and non-additive gene actions were not equally involved in genetic control of researched traits. The GCA $\times$ SCA site interaction was only significant for plant height and grain filling duration, indicating the effects of location on additive mechanisms. The Bakers ratio for days to heading 0.90 and 0.91 at Zarghan and Shiraz respectively, days to maturity 0.81 and 0.82 and seed yield 0.89 and 0.87 in both sites and for plant height 0.88 at Shiraz revealed the great significance of additive mean squares in the genetic control of these characters. The general combining ability estimates showed that Chamran for dwarfness, early heading and maturity and grain filling duration, Darab2 for dwarfness, early heading and maturity, Marvdasht for grain filling duration and grain yield showed best combining abilities. Graphical representation and the average degree of dominance indicated that all characters were controlled through partial dominance.

Beche et al. (2013) estimated the heterosis and inbreeding depression for grain yield and its parameters in crosses involving ten genotypes of wheat. Genotypes and their $F_{1}$ and $F_{2}$ hybrids were estimated under field conditions. The heterobeltiosis, heterosis and inbreeding depression for agronomic characters were estimated. There was a negative correlation between the heterobeltiosis and seed yield/plant inbreeding depression, representing the existence of positive additive $\times$ additive non-allelic interactions. The mean values of seed yield/plant for the F1 and F2 generations were $20 \%$ and $10 \%$ higher, 
respectively, compared with the parents, representing that the hybrids were superior to the parents. The heterosis of the spikes/plant in the F1 and F2 generations can be a valuable method for the indirect selection of wheat plants with an better seed weight and seed yield/plant. The research exposes good choice for separation of pure lines from the progenies of heterotic F1's and commercial exploitation of heterosis in spring wheat.

Bibi et al. (2013) crossed eight genotypes of wheat with Chakwal-50 (control) and used line $\times$ tester analysis to study the spike traits under moisture stress conditions. There were significant differences among lines and testers for most of the characters under stress. The parent GD-153 was best general combiner for spikelets/spike, grain yield/plant and spike density, GD-171 for spike length, while GD-102 for awn length and grains/spike. Whereas, the cross GD-170 $\times$ GD-159 was best to increase spike length and the crosses GD-170 $\times$ GD-159, GD-170 $\times$ GD189 , GD-153 $\times$ GD-171 for yield components. These best genotypes and crosses can be used to develop new varieties for irrigated and rainfed areas.

Fellahi et al. (2013) crossed nine bread wheat genotypes in a line $\times$ tester fashion. The F1's and their parents were evaluated in field conditions. Adequate genetic variability was seen for all observed traits. High mean value for grain yield was observed for A899 $\times$ Rmada, A899 $\times$ Wifak, and A1135 $\times$ Wifak hybrids than their parents. A901 and Wifak were good combiners for the No. of grains/spike. For No. of tillers and 1000-seed weight MD was good combiner. For reducing plant height HD1220 was good general combiner. A901×Wifak was best specific combiner to increase number of kernels per spike and 1000-kernel weight. AA $\times$ MD was a best specific combiner to reduce vegetative growth period and plant height. A899 $\times$ Wifak showed the highest heterosis for grain yield, along with negative heterosis for 1000kernel weight and positive heterosis for spike length.

Hammad et al. (2013) estimated the combining ability of five wheat genotypes viz. V-03138, V-04022, V-04189, PR-94 and 9247. At maturity, the data were recorded for plant height, tillers/plant, spike length, spikelets/spike, days to heading, days to maturity and seed index. Significant variability of combining ability estimates was observed for all traits. Higher SCA variance was measured for most of the traits describing additive genetic effect. Plant height showed non-additive behaviour and days to maturity was under control of cytoplasmic or extra nuclear genes inheritance presenting high variance component due to SCA and reciprocal effects, respectively. V-04022 possessed higher GCA estimates and proved to be best general combiner for most of the traits. Cross hybrids of $\mathrm{V}$ $03138 \times \mathrm{V}-04189$ exhibited higher SCA for tillers per plant, days to maturity and spikelets per spike. Similarly, V-04189 × PR-94 had higher SCA values for seed index and days to heading. $9247 \times \mathrm{V}-04189$ acquired high reciprocal effects followed by PR-94 $\times$ V-04022 and 9247 $\times \mathrm{V}-04189$ for most of the traits under study.

Lohithaswa et al. (2013) studied combining ability for yield parameters, quality related characters and rust resistance in durum and emmer wheat. They crossed five lines and seven testers in line $\mathrm{x}$ tester mating design. The results showed significant variances for lines, testers and line $\mathrm{x}$ tester for $50 \%$ heading days, days to maturity, plant height, peduncle length, spike length, spikes/m2, tillers/plant, seeds/spike, total biomass/plant, thousand grain weight, grain yield/plant, harvest index, leaf rust reaction, protein content and semolina recovery. The GCA/SCA mean square ratio revealed the presence of additive gene action for all traits except grains/spike. Lines Vijay and DK-100 and testers DWR-1006 and Raj-1555 exhibited significant GCA effects for yield related characters. In 14 cross combinations significant SCA effects for yield components were observed.

Nazeer et al. (2013) conducted an experiment on five spring wheat genotypes to observe the genetic control in the expression of different yield contributing characters. The graphical demonstration of variance and covariance showed that peduncle length and leaf area were governed through additive gene action and partial dominance. Characters like productive tillers, plant height, yield/plant and 1000 seed weight showed over-dominance. Epistatic gene actions were not present for all the characters. Presence of dominant genes was observed in genotypes Pak-81, Pasban-90, Chakwal-86 and line 9267 for peduncle length and leaf area. Dominant genes were mainly present in Pak-81, Passban-90 and Chakwal-86 for productive tillers, yield/plant and plant height. Yet, in genotype 9267 great number of dominant genes was present for 1000 seed weight. Most of recessive genes for peduncle length and leaf area were detected in genotypes Pasban-90, Pak-81and 9250. Whereas, 9250, 9267, Pasban-90 and Pak-81 possessed great number of recessive genes for productive tillers, 1000 seed weight, yield/plant and plant height. Additive gene action with partial dominance in the absence of epistasis for the characters such as peduncle length, leaf area, recommended that for desired improvement in these traits selection in early generations would be operative. While for productive tillers, plant height, 1000 seed weight, and yield/plant selection would be operational in the later segregating generation hereafter heterosis breeding may be helpful for genetic development of these characters.

Pimentel et al. (2013) estimated the effects of general combining ability and specific combining ability of wheat lines in later generations and selected superior segregating progenies. Twelve genotypes and their 36 hybrids in $\mathrm{F}_{2}$ and $\mathrm{F}_{3}$ generations, attained in a partial diallel arrangement, were estimated for seed yield. In both generations GCA effect was significant. Maximum correlation (0.83) of the effects of GCA was observed among generations, but expressionless impact of generation's effects and years was obtained on the grouping of crosses. The progenies resulting from the crossing between the genotype BRS 264, IAC 364 (Tucurui III) and BRS 254 the genotypes VI 98053, UFVT1, Pioneiro and MGS 1 Alianca exhibited the highest potential for attaining superior genotypes for seed yield. The utilization of the partial diallel analysis in progressive generations is encouraging for wheat breeding programs.

Raj and Kandalkar (2013) evaluated the combining ability effects of $40 \mathrm{~F}_{1} \mathrm{~s}$ along with parents. Significant variances of general and specific combining ability were observed for yield estimating characters. But GCA variances for No. of productive tillers/plant, main spike weight, first inter node length and grain weight per spike and SCA variances for stem girth. The results indicated that 
most of characters including grain yield were controlled by both additive as well as non-additive inheritance. The combining ability effects showed that parents HD2964, DDW32, DDW11 and HS493 recognized as good general combiners for many traits. The cross combinations, DBW39 × HPW285, SONALIKA $\times$ RAJ4119, MP4010 $\times$ HS493 and MP4010 $\times$ HD2964 were good specific combiners for yield component characters.

Singh et al. (2013) analysed the combining ability using ten genotypes of bread wheat. Results showed that both additive and non-additive genetic components were involved to control different characters. However, the GCA/SCA variances ratio revealed superiority of nonadditive genetic effects in nearly all characters. Genotypes HD 285, WH 789 and Raj 4063 were found as good general combiners, while cross combinations WH $789 \times$ NW 3015 , HUW $468 \times$ UP 2614 and HS $448 \times$ Raj 4063 were best specific combiners for yield/plant and other related characters. However, hybrids of WH $789 \times$ NW 3015, HS $448 \times$ Raj 4063 and K $209 \times$ HD 2851 were most favourable for taking advantage in future breeding programs, on the basis of their performance and significant specific combining ability effects for yield components.

Tahmasebi et al. (2013) assessed the genetic diversity and interrelationship of traits in some of promising wheat lines and determine the traits effecting yield. Fifteen wheat lines and one wheat cultivar were evaluated for agromorphological characters. Analysis of variance showed significant difference between all characters except period of grain filling and No. of grains/spike. Among all traits, higher genetic coefficient variation and phenotypic coefficient variation were observed for grain yield, number of spikes and 1000-grain weight. Correlation analysis showed significant and positive relationship of grain yield with 1000-grain weight, plant height and No. of spikes. In regression analysis, 1000-grain weight, plant height and No. of spikes/plant remained in the final model.

Aslam et al. (2014) used three elite wheat lines viz. 9436, 9444 and 9452 as female parents and three wheat varieties viz. SH-2002, Sehar 2006 and Lasani 2008 as male parents to produce 9 F1 crosses. Parent line 9452 and tester SH-2002 were found good general combiner for yield and its components. $9436 \times \mathrm{SH}-2002,9444 \times \mathrm{SH}-$ 2002, $9452 \times$ Sehar 2006 and $9452 \times$ Lasani 2008 were more promising hybrids for grain yield components. The combining ability studies show that both additive and nonadditive gene effects exist in genetic material.

Barot et al. (2014) crossed the four lines with eight testers to study the combining ability, gene action and heterosis for yield and yield contributing traits in wheat using line $\times$ tester analysis. Results showed that the traits which are under study showed both additive and nonadditive gene action. The traits which showed preponderance of additive gene action in the inheritance have higher general combining ability variances than the specific combining ability variances. GW11 × GW322 were good combiners for grain yield per plant, harvest index and protein content. The highest heterosis over standard check variety (GW 496) for grain yield per plant was registered by the cross GW $503 \times$ GW 190 followed by GW $173 \times$ GW 190, GW $11 \times$ GW 190 and GW $503 \times$ GW 322 .
Noorka and Silva (2014) investigate the morphological and physiological traits under water stressed and normal condition. They used Line $\times$ tester mating design to cross seven water stressed tolerant genotypes (Pakistani, Indian and CIMMYT) with seven local water stressed susceptible lines. The hybrids and parents were sown in two different environments to study the combining ability effects and best combiners for different traits were selected. They concluded that genotypes Neser, Dharwar Dry, Inqlab-91 are good combiners among others while Bakhar-2002 $\times$ 9247, Dharwar Dry $\times 9021$, Bakhar-2002 × 9244, and Nesser $\times 9244$ are good cross combiners. Under normal irrigation genotype 9252 performed best and under waterstressed condition genotype Dharwar Dry performed best in case of grain yield. Different traits showed additive and non-additive types of gene action under both environmental conditions.

\section{Summary}

Wheat production is decreasing due to many stresses and there is need to increase its yield. This review totally gives us the information that what is multi-ovary wheat and how we can use it in our breeding lines to improve our genotype. How it can increase our yield? Because being a breeder main focus is on yield. What is the position of the genes which produce multi-ovary and also found that is there any difference in this and common wheat in the light of different characters. From above studies it is showed that the inheritance of trigrain wheat is not understood. Some support the single dominant gene controlled trait, some support the two recessive non-complementary genes controlled trait and some favour the both as it is controlled by both dominant and recessive genes in different trigrain lines. Above this how combining ability works toward different yield and yield contributing traits. What are the types of gene actions which operate them? This reveals the information about the performance of different lines of wheat toward different types of environment and in different situations. By the selection of different lines we can use it in the breeding programs as parents. Our main focus is to seek the information to lessen all the losses and improve the yield with the raising challenges

\section{References}

Acquaah G. 2006. Principles of plant genetics and breeding. Blackwell publishing, Ltd.

Ahmad F, Khan S, Ahmad SQ, Khan H, Khan A, Muhammad S. 2011. Genetic analysis of some quantitative traits in bread wheat across environments. Afr. J. Agri. Res. 6: 686-692.

Akbar M, Anwar J, Hussain M, Qureshi MH, Khan S. 2009. Line $\times$ tester analysis in bread wheat (Triticum aestivum L.). J. Agri. Res. 47: 411-420

Akram Z, Ajmal S, Khan KS, Qureshi R, Zubair M. 2011. Combining ability estimates of some yield and quality related traits in spring wheat (Triticum aestivumL.). Pak. J. Bot. 43: 221-231

Anonymous. 2015-16. Pakistan Ministry of food, Agriculture and Livestock, Finance Division, Economic Advisor's Wing, Islamabad, Pakistan. pp. 23-41.

Aslam R, Munawar M, Salam A. 2014. Genetic Architecture of Yield Components Accessed Through Line $\times$ Tester Analysis in Wheat (Triticum aestivum L.). Universal J. Plant Sci. 2: 93-96 
Barot HG, Patel MS, Sheikh WA, Patel LP, Allam CR. 2014. Heterosis and combining ability analysis for yield and its component traits in wheat [Triticum aestivum (L.)]. Electronic J. Plant Breed. 5(3): 350-359.

Beche E, Silva CLD, Pagliosa ES, Capelin MA, Franke J, Matei G, Benin G. 2013. Hybrid performance and heterosis in early segregant populations of Brazilian spring wheat. Australian J. Crop Sci. 7(1): 51-57.

Bibi R, Hussain SB, Khan AS, Raza I. 2013. Assessment of combining ability in bread wheat by using line $\times$ tester analysis under moisture stress conditions. Pakistan J. Agri. Sci. 50(1): 111-115.

Cheema NM, Ihsan M, Mian MA, Rabbani G, Tariq MA, Mahmood A. 2007. Gene action studies for some economic traits in spring wheat. Pakistan J. Agri. Res. 20(3/4): 99-104.

Chen, J., Linghua Z, Bingli W. 1983. A preliminary report on the discovery and breeding of the trigrain wheat. Acta agronomica sinic. 9(1): 69-71.

Chowdhry MA, Ambreen A, Khaliq I. 2002. Genetic control of some polygenic traits in Aestivum species. Asian J. Plant Sci. 1(3): 235-237.

Chowdhry MA, Chaudhry MA, Gilani SMM, Ahsan M. 2001. Genetic control of some yield attributes in bread wheat. Pakistan J. Biol. Sci. 4(8): 980-982.

Cox TS, Murphy JP. 1990. The effect of parental divergence on $\mathrm{F}_{2}$ heterosis in winter wheat crosses. Theor. Appl. Genet. 79: 241-150.

Dagustu N. 2008. Genetic analysis of grain yield per spike and some agronomic traits in diallel crosses of bread wheat (Triticum aestivum L.). Turkish J. Agri. For. 32: 249-258.

Dhadhal B, Dobariya K, Ponkia H, Jivani L. 2008. Gene action and combining ability over environments for grain yield and its attributes in bread wheat (Triticum aestivum L.). Int. J. Agri. Sci. 4(1): 66-72.

Dong-xu, Z, Shou-cai M, Gai-sheng Z, Na N. 2010. Molecular Marker Detection of Genetic Background in Near-isogenic Lines with Multi-ovary Character. J. Triticeae Crops. 30(3): 406-410.

Echeverry-Solarte M, Kumar AA, S. Kianian S, Mantovanim EE, Simsek SS, Alamri MS, Mergoum M. 2014. Genome-wide genetic dissection of supernumerary spikelet and related traits in common wheat. The plant genome. 7: 1-16.

Esmail RM. 2007. Detection of Genetic Components Through Triple Test Cross and Line $\times$ Tester Analysis in Bread Wheat. World J. Agri. Sci. 3(2): 184-190.

Fellahi ZEA, Hannachi A, Bouzerzour H, Boutekrabt A. 2013. Line $\times$ tester mating design analysis for grain yield and yield related traits in bread wheat (Triticum aestivum L.). Int. J. Agron. 201851: 1-9.

Gorjanovic B, Balalic MK. 2007. Inheritance of plant height, spike length and number of spikelets per spike in Durum wheat. Proc. Nat. Sci. MaticaSrpska Novi Sad, 102: 27-33.

Gowda M, Longin CFH, Lein V, Reif JC. 2012. Relevance of Specific versus General Combining Ability in Winter Wheat. Crop Sci. 52: 2494-2500.

Guo-hui Z, Gai-Sheng Z, Feng-hui G, Na N, Shou-cai M, Dongliang P, Kui W. 2008. Study on factors influencing penetrance of multiovary in wheat. J. Plant Genet. Resour. 9:528-530.

Hammad G, Kashif M, Munawar M, Ijaz U, Raza MM, Saleem M, Abdullah. 2013. Genetic analysis of quantitative yield related traits in spring wheat (Triticum aestivum L.). Am. Euras. J. Agri. Environ. Sci. 13(9): 1239-1245.

Haq WUl, Malik MF, Rashid M, Munir M, Akram Z. 2008. Evaluation and estimation of heritability and genetic advancement for yield related attributes in wheat lines. Pakistan J. Bot. 40(4): 1699-1702.

Hasnain Z, Abbas G, Saeed A, Shakeel A, Muhammad A, Rahim MA. 2006. Combining ability for plant height and yield related traits in wheat, Triticum aestivum L. J. Agri. Res. 44(3): 167-173.
Huibin DW, Yaozhi W, Jishan N. 1992. Abnormal development of stamen in trigrain wheat. J. Lanzhou Univ. 28: 157-162.

Iqbal M, Khan AA. 2006. Analysis of combining ability for spike characteristics in wheat (Triticum aestivum L.). Int. J. Agri. Biol. 8(5): 684-687.

Jain SK, Sastry E. 2012. Heterosis and combining ability for grain yield and its contributing traits in bread wheat (Triticum aestivum L.). Res. Rev. J. Agri. Allied Sci. 1(1): 17-22.

Jun-Wei W, Gai-Sheng Z, Hong-Wei L, Ya-Zhen S, Na N. 2005. Detection of A RAPD Marker Linked to Dominant Multiovary Gene in Wheat (Triticum aestivum). J. Agri. Biotechnol. 5: 553-556.

Kamaluddin, Singh RM, Prasad LC, Abdin MZ, Joshi AK. 2007. Combining ability analysis for grain filling duration and yield traits in spring wheat (Triticum aestivum L. em. Thell.). Genet. Mol. Biol. 30(2): 411-416.

Kapoor E, Mondal S, Dey T. 2011. Combining ability analysis for yield and yield contributing traits in winter and spring wheat combinations. J. Wheat Res. 3(2): 52-58.

Kashif M, Khan AS. 2008. Combining ability studies for some yield contributing traits of bread wheat under normal and late sowing conditions. Pakistan J. Agri. Sci. 45(1): 44-49.

Kashif M, Khaliq I. 2003. Determination of general and specific combining ability effects in a diallel cross of spring wheat. Pakistan J. Biol. Sci. 6(18): 1616-1620.

Kempthorne O. 1957. An Introduction to Genetic Statistics. John Willey and Sons Inc., New York.

Khaliq I, Chowdhry MA. 2001. Inheritance of yield related traits across environments. Pakistan J. Biol. Sci. 4(7): 829-837.

Khan MA, Ahmad N, Akbar M, Rehman A, Iqbal MM. 2007. Combining ability analysis in wheat. Pakistan J. Agri. Sci. 44(1): 1-5.

Krystkowaik K, Adamski T, Surma M, Kaczmarek Z. 2009. Relationship betwwen phenotypic and genetic diversity of parental genotypes and the specific combining ability and heterosis effects in wheat (Triticum aestivum L.). Euphytica. 165: 419-434.

Kumar A, Thakur KS, Sethi GS, Bhandari JS. 2003 combining ability analysis for grain yield and some other morphophysiological traits in winter $\times$ spring wheat hybrids. Crop Res. Hisar. 26(2): 334-338.

Lohithaswa H, Desai S, Hanchinal R, Patil B, Math K, Kalappanavar I, Bandivadder T, Chandrashekhara C. 2013. Combining ability in tetraploid wheat for yield, yield attributing traits, quality and rust resistance over environments. Karnataka J. Agri. Sci. 26(2): 190-193.

Mahpara S, Ali Z, Ahsan M. 2008. Combining ability analysis for yield and yield related traits among wheat varieties and their $\mathrm{F}_{1}$ hybrids. Int. J. Agri. Biol. 10(6): 599-604.

Majeed S, Sajjad M, Khan SH. 2011. Exploitation of non-additive gene actions of yield traits for hybrid breeding in spring wheat. J. Agri. and Soc. Sci. 7(4): 131-135.

Malano IA. 2008. Line $\times$ tester analysis for estimating combining ability in bread wheat (Triticum aestivum L.). SAUT, Tandojam (Pakistan). Plant genetics breed. Pagination. 100.

Memon S, Qureshi M, Ansari BA, Sial MA. 2007. Genetic heritability for grain yield and its related characters in spring wheat (Triticum aestivum L.). Pakistan J. Bot. 39(5): 15031509.

Narro L, Pandey S, Cross J, Leon CD, Salazar F. 2003. Using line $x$ tester interaction for the formation of yellow maize synthetics tolerant to acid soils. Crop Sci. 43: 1718-1728.

Nazeer W, Hussain T, Khan MA, Naeem M, Amjid MW, Hussain K. 2013. Mechanism of Inheritance for Quantitative Traits in Intera-Specific Crosses of Triticum aestivum L. World Applied Sci. J. 22(10): 1440-1448.

Noorka IR, Teixeira JA, Silva D. 2014. Physical and morphological markers for adaptation of drought-tolerant wheat to arid environments. Pak. J. Agri. Sci. 51(4): 943-952. 
Oettler G, Burger H, Melchinger AE. 2008. Heterosis and combining ability for grain yield and other agronomic traits in winter triticale. Plant breed. 122(4): 318-321.

Oettler G, Becker HC, Hoppe G. 2001. Heterosis for yield and other agronomic traits of winter triticale $F_{1}$ and $F_{2}$ hybrids. Plant. Breed. 120: 351-353.

Pimentel AJB, Souza MAD, Carneiro PCS, Rocha JRDAS, Machado JC, Ribeiro G. 2013. Partial diallel analysis in advanced generations for selection of wheat segregating populations. Pesq. Agropec. Brasileira. 48(12): 1555-1561.

Pimentel AJB, Souza MAD, Carneiro PCS, Rocha JRDAS, Machado JC, Ribeiro G. 2013. Partial diallel analysis in advanced generations for selection of wheat segregating populations. Pesq. Agropec. Brasileira. 48(12): 1555-1561.

Raj P, Kandalkar VS. 2013. Combining ability and heterosis analysis for grain yield and its components in wheat. J. Wheat Res. 5(1): 45-49.

Rashid MAR, Khan AS, Iftikhar R. 2012. Genetic Studies for Yield and Yield Related Parameters in Bread Wheat. Am. Euras. J. Agric. Environ. Sci. 12(12): 1579-1583.

Saeed A, Khan AS, Khaliq I, Ahmad R. 2010. Combining ability studies on yield related traits in wheat under normal and water stress conditions. Pakistan J. Agri. Sci. 47(4): 345-354.

Saeed A, Chowdhry MA, Saeed N, Khaliq I, Johar M. 2001. Line $\times$ tester analysis for some morpho-physiological traits in bread wheat. Int. J. Agri. Biol. 3(4): 444-447.

Senapati N, Swain S, Patnaik M. 2000. Combining ability and nature of gene action in bread wheat. Environ. Ecol. 18(1): 258-260.

Shabbir G, Kiran T, Akram Z, Tabassum MI, Nawaz K. 2012. genetics of some biometric traits in bread wheat (Triticum aestivum L.). J. Agri. Res. 50(4): 457-468.

Sheikh S, Singh I. 2000. Combining ability analysis in wheat plant characters and harvest index. Int. J. Trop. Agri. 18(1): 29-37.

Shen G, Yizhong T, Ghezi S. 1992. Localization of the gene multi-ovary on chromosome and chromosome arm of common wheat using monosomic and ditelosomic analysis. Acta Genetica Sinic. 19(6): 513-516.

Shou-cai M, Gai-sheng Z, Na N. 2007. Breeding of near-isogenic lines of multi-ovary character in wheat and their genetic background evaluation. J. Nuclear Agri. Sci. 21(6): 585-588.

Shou-cai M, Gaisheng Z, Hongwei L, Junwei W. 2002. Studies on the application of multi-ovary character to hybrid wheat. II. Heterosis and utilization of multi-ovary wheat. Acta Botanica Boreali-Occidentalia Sinic. 22(6): 1295-1299.

Shou-cai M, Gaisheng, Hongwei, Junwei W. Xiaoli W. 2000. Studies on the application of multi-ovary character to hybrid wheat. Acta Botanica Boreali-Occidentalia Sinic. 20(6): 949953.

Singh K, Singh UB, Sharma SN. 2013. Combining ability analysis for yield and its components in bread wheat (Triticum aestivum L. em. Thell.). J. Wheat Res. 5(1): 63-67.

Skovmand B, Reynolds MP, DeLacy IH. 2001. Mining wheat germplasm collections for yield enhancing traits. Euphytica 119: 25-32.

Spraugue GF, Tatum LA. 1942. General versus specific combining ability in single crosses of corn. J. Amer. Soc. Agron. 34: 923-932.

Srivastava MK, Singh D, Sharma S. 2012. Combining ability and Gene action for seed yield and its components in Bread Wheat (Triticumaestivum L.). Electronic J. Plant Breeding, 3(1): 606-611.
Suleyman, S. Akguni N. 2007. Combining ability and inheritance of some agronomical traits in braed wheat (Triticum aestivum L.). Ziraat Fakültesi Dergisi. 21(41): 104-108.

Tahmasebi G, Heydarnezhadian J, Aboughadareh AP. 2013. Evaluation of yield and yield components in some promising wheat lines. Int. J. Agri. Crop Sci. 5(20): 2379-2384.

Tong YZ, Tong P. 1984. 1984. Studies on multi-ovary in common wheat I; The morphogenesis of multi-ovary in common wheat and the chromosomal location of its genes. J. Shanghai Norm. Univ. 2: 48-53.

Tonk FA, Ilker E, Tosun, M. 2011. Quantitative inheritance of some wheat agronomic traits. Bulgarian J. Agri. Sci. 17(6): 783-788.

Tripathi S, Marker S, Pandey P. Jaiswal K, Tiwari, D. 2011. Relationship between some morphological and physiological traits with grain yield in bread wheat (Triticum aestivum $\mathrm{L}$. em. Thell.). Trends Appl. Sci. Res. 6: 1037-1045.

Tsenov N, Tsenova E. 2011. 2011. Combining ability of common winter wheat cultivars (Triticum aestivum L.) by date to heading and date to physiological maturity. Bulgarian J. Agri. Sci. 17(3): 277-287.

Wang Y, Jishi C, Huibin D, Lunshan W. 1987. Megasporogenesis and development of embryo sac of trigrain wheat. Acta Botanica Boreali-occidentalia Sinic. 7(8): 163-169.

Wang Y, Huibin D, Jishi C. 1990. Differentiation of additional pistils in a trigrain wheat. J. Lanzhou Univ.(natural sciences). 26(1): 80-84.

Wang Z, Xu DDJ, Ji JJ, Wang JM, Wang MH, Ling HG, Sun G, Li J. 2009. Genetic analysis and molecular markers associated with multi-gynoecia $(\mathrm{Mg})$ gene in Trigrain wheat. Can. J. Plant Sci. 89: 845-850.

Wu J, Li, BQ, Zhao JX. 2000. Genetic analysis of multi-ovary character of trigrain wheat. Acta Agri. Univ. Boreali-Occid. 28: 58-60.

Xian FL, Shou-cai M, Gai-sheng Z, Na N. 2011. Cloning and expression analysis of rpl21 gene in wheat (Triticum aestivum L.). J. Nuclear Agri. Sci. 25(1): 6-13.

Xian FL, Shou-cai M, Gai-sheng Z, Na N. 2011. Cloning of ribosomal protein s15a gene (TaRPS15a) and its expression patterns based on temporal-spatial in multi-ovary line of wheat (Triticum aestivum). J. Agri. Biotechnol. 19(2): 236242.

Xian FL, Shou-cai M, Gai-sheng Z, Na N, Wei F, Rebonoang T, Zhao H. 2011. Identification and expression analysis of genes related to multi-ovary in wheat (Triticum aestivum L.). Seed Sci. and Technol. 20: 54-73.

Yao-zhi W, Hui-bin D, Zhi-lan, J. 1989. Initiation and development of flowers in a multi-pistil wheat. Acta Botanica Boreali-occidentalia Sinic. 9: 131-135.

Yucel C, Baloch FS, Ozkan H. 2009. Genetic analysis of some physical properties of bread wheat grain (Triticum aestivum L. em Thell). Turkish J. Agri. For. 33: 525-535.

Zai-jun Y, Li-Juan P. 2013. 2013. Heritability analysis of main agronomic traits in common wheat line three pistils. J. China West Norm. Univ. (Nat. Sci.), 1: 01-04.

Zai-Jun Y, Zheng-song P, Yong-hong Z, Li-juanand P, ShuHong W. 2012. Evaluation on the genetic background of wheat near isogenic lines for three pistils character by SRAP markers. J. Nuclear Agri. Sci. . 1: 22-27.

Zare-kohan M, Heidari B. 2012. Estimation of genetic parameters for maturity and grain yield in diallel crosses of five wheat cultivars using two different models. J. Agri. Sci. 4(8): 74-85. 